Creative Commons User License: CC BY-NC-ND

Abstracted by: EBSCOhost, Electronic Journals Service (EJS),

Google Scholar, Journal Seek, Scientific Commons,

Food and Agricultural Organization (FAO), CABI and Scopus

http://eoi.citefactor.org/10.11226/v25i4
Journal of Agricultural Extension

Vol. 25 (4) October, 2021

ISSN(e): 24086851; ISSN(Print); 1119944X

http://journal.aesonnigeria.org

http://www.ajol.info/index.php/jae

Email: editorinchief@aesonnigeria.org

\title{
Herbaceous Farmers' Linkage to Grocery Stores in Ondo State, Nigeria
}

https://dx.doi.org/10.4314/jae.v25i4.2

\section{Wole-alo, Felicia Itunnu}

Department of Agricultural Extension and Communication Technology Federal University of Technology, Akure. Nigeria. fellymee@yahoo.com. Or fiwolealo@futa.edu.ng.

Phone: +23480034130029

\section{Alokan, Agnes Olubunmi}

Department of Agricultural Extension and Economics, National Agricultural Extension and Research Liaison Services, Ahmadu Bello University, Zaria. agnesslopez@yahoo.com or agnesalokan@naerls.gov.ng Phone: +2348038029532

\begin{abstract}
This study examined linkage between herbaceous farmers and grocery stores in Ondo State, Nigeria. A multi stage sampling procedure was used to select 96 respondents for the study. Interview schedule was used to elicit information while data were analysed using percentages, mean, and the Pearson Product Moment Correlation. The results revealed that all the respondents (100\%) of the herbaceous farmers got information from input suppliers, which can enhance their linkage to grocery stores. However, the linkage between the herbaceous farmers and groceries store was low. Increase profitability $(\overline{\mathrm{x}}=4.7)$ and increase yield $(\overline{\mathrm{x}}=4.3)$ were major factors that encouraged the farmers to sell to grocery stores. Result showed that farmers' age, educational level and farm size influence farmers 'linkage to grocery stores. There is need for the state government and other non-governmental bodies to create awareness and training for farmers on how to get connected with grocery stores other than just selling at the local markets.
\end{abstract}

Keywords: Herbaceous plants in grocery stores

\section{Introduction}

Vegetable production has been practiced for many decades in Nigeria, providing employment and income for the increasing population. Vegetable produces the micronutrients for the body, antioxidants and phytochemicals that may protect people against non-communicable diseases (Ülger, Songur, Çırak, \& Çakıroğlu,2018), this corroborates the position of Kaur\& Aeri (2019) that reiterates the importance of consuming vegetables as it helps prevents communicable diseases and it's vital to keeping fit and in health, some protective properties against ulcers induced experimentally, have been found in some vegetables, making it a cheap and natural anti-ulcer remedy. These properties found in vegetables are found to be anticarcinogenic in nature and could enhance the immune system Li\& Liu (2018). Vegetables are edible parts of plant that are eaten raw or cooked. These may be root (carrot), fresh pod (green beans), immature fruit (okra), ripe fruits (tomato), tender leaf (Amaranthus), shoot (bamboo), immature flower (cauliflower), shoot or bulb (onion). 
Creative Commons User License: CC BY-NC-ND

Abstracted by: EBSCOhost, Electronic Journals Service (EJS), Google Scholar, Journal Seek, Scientific Commons,

Food and Agricultural Organization (FAO), CABI and Scopus
Journal of Agricultural Extension

Vol. 25 (4) October, 2021

ISSN(e): 24086851; ISSN(Print); 1119944X

http://journal.aesonnigeria.org

http://www.ajol.info/index.php/jae

Email: editorinchief@aesonnigeria.org

Vegetable production and consumption have the potential to create employment and generate income in the developing world. This corroborates the position of Juma, Omondi, \& Kareri, (2018) that affirms the potential of vegetable production in generating employment effectively and Agbugba, \& Shelaby (2018). This is in line with the position of Effiong, Aboh, \& Aya, (2021), which reveals that studies have shown that vegetable has high market potential and also contributes highly to household income, livelihood and nutrition.

However, production is constrained by inadequate infrastructure, inadequate knowledge of agronomic practices, marketing and storage. The marketing of goods and services involves the movement of goods from the producers to consumers (Mukaila, Obetta, Awoyelu, Chiemela \& Ugwu, 2021). Several efforts are made on improving the production of these crops but marketing and linkage of the farmers with the value chain actors have suffered neglect by the actors. There is the need for information on marketing and prevention of post-harvest losses which can in turn improve income. In developed countries, the herbaceous farmers sell to grocery stores and have good network which foster their profitability and marketing of produce. Linkage between farmers and grocery stores in Nigeria is far below what is obtainable in other developed countries, the traditional informal markets and middle men or farm gates are still the major source of vegetable distribution. Many kilograms of herbaceous plants get wasted everyday as a result of inability of farmers to get the connections to the right market. As such there is need for the value chain actors to improve the vegetable production and marketing commodities, making it more competitive as well as harnessing innovations and best practices as to increase the market shares and profit (Effiong, Aboh, \& Aya, 2021),

Despite the potential of vegetable been a realistic business opportunity for people, there had been reported cases of post-harvest losses due to the perishable nature and low profit. The farmers are also faced with inability of getting appropriate market for the harvested products. Which brings to concern, the role of the various actors in the value chain, and the linkage that exist between these actors. Given the grocery store as a marketing channel and the adequacy of such market which has been used effectively in marketing other products. Specifically, the study identified the sources of information to herbaceous farmers on groceries stores;

1. determined the motivating factors that encourage herbaceous plant farmers to sell to groceries stores and

2. ascertained the linkage that exists between the herbaceous farmers and the value chain actors.

The study hypothesized that there is no significant relationship between the socioeconomic characteristics of the herbaceous plant farmers and how they are connected to grocery stores. 
Creative Commons User License: CC BY-NC-ND

Abstracted by: EBSCOhost, Electronic Journals Service (EJS),

Google Scholar, Journal Seek, Scientific Commons,

Food and Agricultural Organization (FAO), CABI and Scopus

http://eoi.citefactor.org/10.11226/v25i4
Journal of Agricultural Extension

Vol. 25 (4) October, 2021

ISSN(e): 24086851; ISSN(Print); 1119944X

http://journal.aesonnigeria.org

http://www.ajol.info/index.php/jae

Email: editorinchief@aesonnigeria.org

\section{Methodology}

The study was carried out in Ondo State which lies on a coordinate of $7^{\circ} 10^{\prime} \mathrm{N} 5^{\circ} 05^{\mathrm{I}} \mathrm{E} /$ $7.167^{\circ} \mathrm{N} 5.083^{\circ} \mathrm{E}$. A multi stage sampling procedure was used to select respondents for the study, the first stage was a purposive sampling technique to select 2 local government areas which are Akure South L.G.A. and Akure North L.G.A due to high production of herbaceous plants in the areas (vegetables).

The second stage involved a cluster sampling where one cluster was selected from Akure South and Akure North local government areas. Finally, at the cluster level, simple random sampling was applied to select $50 \%$ of the herbaceous farmers from each cluster. Thus, a total of 96 respondents formed the sample size of the study. Descriptive statistics namely frequency and percentages were used to present results based on the objectives and Pearson Product Moment Correlation was used to establish the correlation between the socio-economic characteristics of the herbaceous plant farmers and their connection to grocery stores $\left(\mathrm{Ho}_{1}\right)$ :.

\section{Results and Discussion}

\section{Sources of information to herbaceous farmers on grocery stores}

Results in Table 1 indicate how herbaceous plant farmers get information from the value chain actors. Results show that all (100\%) of the farmers indicated their connections with input suppliers, and their main source of information as input suppliers, transporters and middle men. This implies that if such information is utilized is capable of enhancing their linkage to grocery stores, and in turn helps limit post-harvest losses. Enhance marketing as alternative channel of marketing produce will be harnessed. This is in tandem with the finding of Mukaila, Obetta, Awoyelu, Chiemela \& Ugwu, (2021) that middlemen played important role in giving out information concerning marketing of vegetables.

Table 1: Herbaceous farmers' sources of information on grocery stores

\begin{tabular}{ll}
\hline Actors & $\begin{array}{l}\text { Yes } \\
(\%)\end{array}$ \\
\hline Input Suppliers & 100.0 \\
Transporter & 98.9 \\
Middle men & 93 \\
Cooperative society & 2 \\
Ondo State Government & 2 \\
Processors & 25 \\
\hline
\end{tabular}

Source: Field survey, 2020

\section{Factors that Encourage Herbaceous Plant Farmers to Sell to Grocery Stores}

Results in Table 2 show that increase in profitability $(\bar{x}=4.71)$, increase in yield $(\bar{x}=$ 4.31) and reduction in market loss $(\bar{x}=4.23)$ were the major factors that motivated the farmers to sell to grocery stores. This implies that herbaceous farmers who 
Creative Commons User License: CC BY-NC-ND

Abstracted by: EBSCOhost, Electronic Journals Service (EJS), Google Scholar, Journal Seek, Scientific Commons,

Food and Agricultural Organization (FAO), CABI and Scopus
Journal of Agricultural Extension

Vol. 25 (4) October, 2021

ISSN(e): 24086851; ISSN(Print); 1119944X

http://journal.aesonnigeria.org

http://www.ajol.info/index.php/jae

Email: editorinchief@aesonnigeria.org

aimed at improved profitability are motivated to sell to grocery stores so as to increase profit of their produce. Increase in yield is another factor as large-scale farmers or farmers with increased yield harnesses better market opportunities. Reduction in market loss was also a factor that was identified, as vegetables are perishable and gets spoilt very fast, hence in preventing this loss, farmers are motivated to sell to grocery stores. This finding is in line with the position of (Akinwale, \& Oyeyemi, 2021) that vegetables are common items found at grocery stores in cities now so as to improve their livelihood and also as to afford farmers with better market access of their products.

Table 2. Motivating factors to sell to groceries stores

\begin{tabular}{lcc}
\hline $\begin{array}{l}\text { Factors that encourage } \\
\text { herbaceous plant } \\
\text { farmers }\end{array}$ & Mean & $\begin{array}{l}\text { Standard } \\
\text { deviation }\end{array}$ \\
\hline Increase in profitability & 4.7083 & .00958 \\
$\begin{array}{l}\text { Increase in yield } \\
\begin{array}{l}\text { Reduction in marketing } \\
\text { loss }\end{array}\end{array}$ & 4.3125 & .03104 \\
Facilitating technologies & 4.2396 & .05692 \\
$\begin{array}{l}\text { Ultimate market } \\
\text { information }\end{array}$ & 4.2083 & .00202 \\
$\begin{array}{l}\text { Strong bond with value } \\
\text { chain actors }\end{array}$ & 4.0312 & .01028 \\
$\begin{array}{l}\text { Premium price at point of } \\
\text { sales }\end{array}$ & 3.9896 & .04715 \\
$\begin{array}{l}\text { Guaranteed/ stable } \\
\text { markets }\end{array}$ & 3.8333 & .03472 \\
$\begin{array}{l}\text { Lower marketing cost } \\
\text { Financial supports }\end{array}$ & 3.7604 & .04739 \\
\hline
\end{tabular}

Source: Field survey, 2020

\section{Linkage between Herbaceous Plant Farmers and Value Chain Actors}

Table 3 shows that the linkage with the value chain actors on information sourcing, marketing and rate at which contact is made, the middle men ranked first as linkage between the herbaceous famers and value chain actors. It is evident from this Table that the linkage between the herbaceous farmers and grocery stores is low as well as the cooperative society and Ondo state government compared to the linkage to actors such as middlemen, transporters and input suppliers. The low linkage of the herbaceous farmers and grocery stores is in line with the findings of Akinwale, \& Oyeyemi, (2021), that a low linkage exist between the vegetable farmers and supermarket. 
Creative Commons User License: CC BY-NC-ND

Abstracted by: EBSCOhost, Electronic Journals Service (EJS), Google Scholar, Journal Seek, Scientific Commons,

Food and Agricultural Organization (FAO), CABI and Scopus

http://eoi.citefactor.org/10.11226/v25i4
Journal of Agricultural Extension

Vol. 25 (4) October, 2021

ISSN(e): 24086851; ISSN(Print); 1119944X

http://journal.aesonnigeria.org

http://www.ajol.info/index.php/jae

Email: editorinchief@aesonnigeria.org

Table 3: Linkage between herbaceous plant farmers and the value chain actors

\begin{tabular}{lll}
\hline $\begin{array}{l}\text { Value chain } \\
\text { Actors }\end{array}$ & Mean & $\begin{array}{l}\text { Standard } \\
\text { deviation }\end{array}$ \\
\hline Middlemen & - & .0876 \\
Transporter & 2.34 & 0.560 \\
Input suppliers & 1.93 & 0.056 \\
Groceries stores & 1.47 & 0.004 \\
Cooperative & .031 & 0.006 \\
society & & \\
Ondo State & .031 & 0.085 \\
Government & & \\
Processors & .302 & 0.345 \\
\hline
\end{tabular}

Source: Field survey, 2020

Influence of Socio-Economic Characteristics on linkage to Grocery Stores

Table 4 reveals that there was a significant and positive relationship between farmers' age

$(r=0.678)$, educational levels $(r=0.537))$, farmers farm size $(r=0.745))$ and how they are linked to grocery stores. The positive correlation between farmers age and linkage to grocery could mean that with age comes experience and by extension their experience with grocery stores which could afford farmers in informed decisions making that are beneficial. It might also imbue them with more understanding in harnessing the grocery store as marketing channel. The educational level was also significant; education being a variable that has been found to help one make better decisions. This might have predisposed them to taken opportunities and linkages offered by grocery stores. Respondents in this study are averagely educated and the more educated the more the inclination to market commodities through the grocery stores.

The farm size was also significant as higher farm size predisposes one to harness better marketing channels due to the level of output, alternatives that are beneficial such as the grocery stores will be harnessed. The findings contradicts the findings of Akinwale, \& Oyeyemi, (2021), who found no correlation of age, educational level, farmers farm size and

linkage to grocery stores as it does not influence the linkage of farmers to grocery stores in their study. 
Creative Commons User License: CC BY-NC-ND

Abstracted by: EBSCOhost, Electronic Journals Service (EJS),

Google Scholar, Journal Seek, Scientific Commons,

Food and Agricultural Organization (FAO), CABI and Scopus

http://eoi.citefactor.org/10.11226/v25i4
Journal of Agricultural Extension

Vol. 25 (4) October, 2021

ISSN(e): 24086851; ISSN(Print); 1119944X

http://journal.aesonnigeria.org

http://www.ajol.info/index.php/jae

Email: editorinchief@aesonnigeria.org

Table 5: Relationship between the herbaceous plant farmers and linkage to groceries stores.

\begin{tabular}{ll}
\hline Variables & r-value \\
\hline Age & $0.678^{\star}$ \\
Education level & $0.537^{\star}$ \\
Household size & -0.073 \\
Years of herbaceous farming & 0.056 \\
Farmers farm size & $0.745^{\star}$
\end{tabular}

- $\quad \mathrm{P} \leq 0.05$. Source: Field survey, 2020

\section{Conclusion and Recommendations}

Increase in profitability, yield and reduction in marketing loss were the factors that motivate the farmers to sell to groceries stores. The middle men ranked first as linkage between the herbaceous famers and value chain actors. Farmers' age, educational level and farm size influenced herbaceous farmer's linkage to the grocery's stores. But the linkage between the herbaceous farmers and groceries store was low.

There should be enlightenment from the Ondo state government and relevant stakeholders on how farmers can get their herbaceous across to various markets such that they are not limited to local markets and middle men. Efforts should be made by the Ondo state government in creating an innovation platform where the stakeholders can easily meet, exchange ideas, get market information and market products easily. Cooperative bodies should not only provide credit to the farmers but also should help in getting other channels through which the farmers can sell (cooperative marketing).

\section{References}

Agbugba, I. K., \& Shelaby, A. (2018). Marketing Analysis of Selected Vegetables in Port Harcourt Metropolis Rivers State, Nigeria. IOSR-Journal of Agriculture and Veterinary Science (IOSR-JAVS), 11(2), 26-34.

Akinwale, J. A., \& Oyeyemi, O. V. (2021). Effectiveness of linking vegetable farmers to formal markets in Lagos State, Nigeria. Journal of Agriculture and Natural Resources, 4(2), 273-283. DOI: https://doi.org/10.3126/janr.v4i2.33920

Effiong, J. B., Aboh, C. L., \& Aya, C. F. (2021). Perception of farmers on the contribution of vegetables to livelihoods in Yakurr local government area, Cross River state, Nigeria. Global Journal of Pure and Applied Sciences, 27(2), 85-91.

Juma, E. A., Omondi, P., \& Kareri, R. W. (2018). Effect of youth engagement in vegetable

farming on household well-being in Kakamega Town, Kenya. Journal of Geography and Regional Planning, 11(8), 
Creative Commons User License: CC BY-NC-ND

Abstracted by: EBSCOhost, Electronic Journals Service (EJS), Google Scholar, Journal Seek, Scientific Commons,

Food and Agricultural Organization (FAO), CABI and Scopus

http://eoi.citefactor.org/10.11226/v25i4
Journal of Agricultural Extension

Vol. 25 (4) October, 2021

ISSN(e): 24086851; ISSN(Print); 1119944X

http://journal.aesonnigeria.org

http://www.ajol.info/index.php/jae

Email: editorinchief@aesonnigeria.org

Kaur, H., \& Aeri, B. T. (2019). Protective Impact of Fruits and Vegetable Intake on Cardiovascular Risk Factors-A Review. Journal of Clinical \& Diagnostic Research, 13(5).

Li, G., \& Liu, D. (2018). The protective role of Vitamin C and Vitamin C-containing foods in Head and neck cancer. International Journal of Clinical and Experimental Medicine, 11(1), 347-353.

Mukaila, R., Obetta, A. E., Awoyelu, F. E., Chiemela, C. J., \& Ugwu, A. O. (2021). Marketing Analysis of Vegetables: The case of carrot and Cucumber Marketing in Enugu State, Nigeria. Turkish Journal of Agriculture-Food Science and Technology, 9(2), 346-351.

Ülger, T. G., Songur, A. N., Çırak, O., \& Çakıroğlu, F. P. (2018). Role of vegetables in human nutrition and disease prevention. Vegetables-Importance of Quality Vegetables to Human Health; Intech Open: London, UK, 7-32. DOI: 10.5772/intechopen.77038. Available from: https://www.intechopen.com/chapters/6169

Wole-Alo F.I. and Oluwagbemi I.O (2020). Adoption and Utilization of ICT Through Farmers.NG Technology in Ondo State, Nigeria. International Journal of Applied Agricultural Sciences. 6(1), 7-15. Doi: 10.11648/j.jjaas.20200601.12 